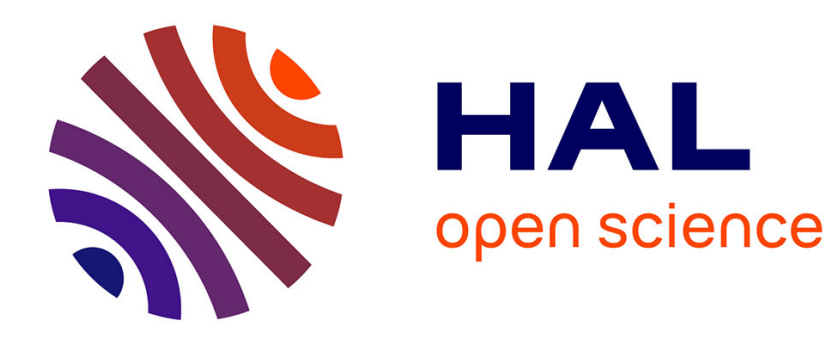

\title{
Optical filters by the pyrolysis of metal-organics
}

S. Desu

\section{- To cite this version:}

S. Desu. Optical filters by the pyrolysis of metal-organics. Journal de Physique IV Proceedings, 1993, 03 (C3), pp.C3-391-C3-391. 10.1051/jp4:1993354 . jpa-00251411

\section{HAL Id: jpa-00251411 https://hal.science/jpa-00251411}

Submitted on 1 Jan 1993

HAL is a multi-disciplinary open access archive for the deposit and dissemination of scientific research documents, whether they are published or not. The documents may come from teaching and research institutions in France or abroad, or from public or private research centers.
L'archive ouverte pluridisciplinaire HAL, est destinée au dépôt et à la diffusion de documents scientifiques de niveau recherche, publiés ou non, émanant des établissements d'enseignement et de recherche français ou étrangers, des laboratoires publics ou privés. 


\title{
Optical filters by the pyrolysis of metal-organics
}

\author{
S.B. DESU
}

Department of Materials Science and Engineering, Virginia Polytechnic Institute and State University, Blacksburg, VA 24061, U.S.A.

\begin{abstract}
Optical coatings and filters have enormous applications in every branch of modern optics. Traditionally optical films are deposited by evaporation, sputtering, and by chemical methods. Using these above mentioned techniques it is very difficult to obtain excellent quality films; that is, films with extremely low values of scattering, absorption and film stress and high corrosion resistance to humidity. Recently developed IonAssisted Deposition techniques produce high performance films but suffer with high cost and their difficulty to coat odd shaped objects.

Pyrolysis of metal-organics at low pressures besides being low cost deposition method, offer several advantages over the traditional techniques. The resulting films are usually theoretically dense and also very pure; thus light scattering and impurity absorption are respectively minimized. The method has no inherent limitation in size, thickness and shape of the deposit which can be produced. Furthermore, the film thickness can be precisely controlled.
\end{abstract}

The present talk focuses on the technique: pyrolysis of metal-organics as applied to infrared reflecting multilayer interference filters for lightning applications. Special attention will be paid to pyrolysis mechanisms, film stress minimization, and large-scale production issues. 